International Journal of English Literature and Social Sciences
Vol-6, Issue-5; Sep-Oct, 2021
Journal Home Page Available: https://ijels.com/
Journal DOI: $10.22161 / \mathrm{ijels}$

Peer-Reviewed Journal

\title{
Discourse Markers in Journalism: A Case in Compostela Valley State College-Maragusan
}

\author{
Kei Inansugan, $\mathrm{MAED}^{1}$; Kethelle Sajonia, $\mathrm{MDC}^{2}$; Nelson Pastolero, Ph.D. ${ }^{3}$
}

\author{
${ }^{1}$ Faculty, Davao de Oro State College, Maragusan, Davao de, Philippines \\ ${ }^{2}$ Faculty, University of Southeastern Philippines, Davao City, Philippines \\ ${ }^{3}$ Faculty, Davao Oriental State University, Mati, Davao Oriental, Philippines
}

Received: 21 Sep 2021; Received in revised form: 14 Oct 2021; Accepted: 23 Oct 2021; Available online: 29 Oct 2021 (C)2021 The Author(s). Published by Infogain Publication. This is an open access article under the CC BY license (https://creativecommons.org/licenses/by/4.0/).

\begin{abstract}
This study mainly explored the use of Discourse Markers (DMs) in journalistic writings and the factors that prompted the BSED English students of CVSC Maragusan to commit errors. This study employed the qualitative research. Ten (10) informants were part of the writing assessment and phone interview and were chosen through purposive sampling. For ethical considerations, this study underwent an ethics review before the data were gathered. Furthermore, to adhere to the Data Privacy Act, the identity of the respondents was held confidential. The Coding and thematic analysis were used in data analysis. The study's findings revealed that students have limited knowledge about DMs and their functions in basic writing. Additionally, the limited knowledge about DMs are the factors that prompted the respondents to commit errors in using the DMs in their journalistic writings. These findings imply that students should be taught more about the DMs, their types, and their proper usage in writing. With this, the incorporation of the DMs in the discussion should be given more attention, especially in writing class.
\end{abstract}

Keywords-discourse markers, journalistic writings, error analysis.

\section{INTRODUCTION}

Writing is one of the four macro skills that is an important tool for learning since it aids learners in various ways, including comprehension of views and ideas. It develops the capacity for explaining and refining ideas both to others and to oneself (Sadiku, 2015). However, writing using the foreign language adds another layer of difficulty. Learning to write using the second language needs intentional and conscious teaching or direction for each linguistic aspect. To write sentences correctly, learners must be acquainted with many writing components, such as grammar, punctuation, and spelling (Safa, 2018). Additionally, awareness of DMs may greatly assist students in writing successfully. These discourse markers help to enhance the quality of writing and the readability of content.

The shared purpose of language usage may lead to general patterns of the linguistic structure being adopted by writing texts in different genres; however, as argued by
(Javadi-Safa, 2018), language in writing discourse may be affected by disciplines or purposes and thus show variations in the actual application. Text-producers are needed to utilize DMs in a particular manner anticipated and approved by their text-receivers to create acceptable, natural, and communicatively successful texts. As a result, understanding the role of discourse markers as components that contribute to the acceptability, naturalness, and efficacy of texts is critical for anyone studying writings in any language.

In Compostela Valley State College (CVSC) Maragusan, an interview with some English instructors was conducted. Balmera (personal communication, 2021) asserted that English majors usually commit grammatical errors due to the inappropriate usage of DMs in their sentences. Lumayno (personal communication, 2021), a former instructor and student publication adviser, supported the claim, emphasizing students' difficulties 
with their basic writing skills, specifically the repetitive errors in using DMs on student outputs.

Generally, the above statements persuaded the researcher to fill in the existing knowledge gap. Because writing coherently is necessary for conveying full information, it remains a required ability for all students and workers as they prepare for higher education or job. (Beyreli and Konuk 2018). Better communication, more structured writing, better comprehension of texts, and speech will result from the usage of DMs, which will improve learners' speaking, writing, listening, and reading skills. Also, Hamed (2018) asserted that DMs could considerably improve academic and technical reporting.

The researchers intended to investigate the use of DMs in journalism in order to uncover common errors made by students in various genres. It would lead to an efficient understanding of concepts and structure in basic written discourse. Therefore, this study would help both the students and the teachers in CVSC Maragusan choose the correct Discourse Markers in writing.

\section{METHODOLOGY}

This case study employed a qualitative design of research using error analysis. According to Rahman (2016), qualitative research focused on analyzing the subjective meaning or the social production of issues, events, or practices by collecting non-standardized data and analyzing texts and images rather than numbers and statistics. Moreover, qualitative research refers to how people make sense of their world and the experiences they have in the world (Holloway and Wheeler, 2010).

Furthermore, this study applied case analysis. In this study, the researcher focused on common errors in using DMs in the journalistic writings of the students.

This study also used data coding and thematic analysis to analyze the participants' responses to the interview questions to be asked. Data coding is defined as the procedure of classifying texts to form explanations and broad themes in the data (Creswell, 2007). According to, Creswell (2007) cited by Akinyode and Khan (2018), the thematic analysis aims to explore and understand a subject or the denotation of an idea.

Moreover, the researcher used the error analysis design. This is a type of qualitative approach that is under the branch of applied linguistics. This is concerned with the compilation, study, and analysis of errors made by language learners and aims at investigating aspects of second language acquisition (Akinyode and Khan, 2018).

Likewise, the discourse markers classified by Fraser (1999) were applied to serve as the basis for the error analysis study. According to Fraser (1999) Discourse Markers Model, discourse markers can be categorized as elaborative markers, contrastive markers, inferential markers, and temporal markers. This study on the use of discourse markers in the journalistic writings of $2^{\text {nd }}$ year BSED English students fell naturally under the qualitative research umbrella since its results will rely more on understanding the different markers used.

Additionally, the error analysis was based on Stephen Corder's Error Analysis Theory, which required that the corpora and use of discourse markers be analyzed beyond the sentential level. It will be used to analyze learners' errors in second and foreign language learning. This will be used since error analysis can provide insight into complex language development processes and a structured way to define, describe and explain student errors. (Jabeen, Kazemian, and Shabaz Mustafai, 2015).

\section{FINDINGS}

This qualitative case study discusses the used Discourse Markers (DMs) in the journalistic writings of the respondents and the errors committed. It also includes the respondents' views about what prompted them to commit errors in using DMs in writing.

To generate the data, the students were first asked to write one article for each of the three different genres of journalism, namely News, Feature, and Editorial. There are a total of thirty (30) articles collected from the respondents. The outputs were then checked and dissected the DMs present using the Discourse Markers Model by Fraser. Next, the DMs were evaluated for error analysis using Corder's Error Analysis model. Lastly, the respondents were interviewed via phone interview about the errors they have committed and possible reasons. This is to ensure that responses are valid and sufficient for this study

\subsection{Discourse Markers in the Journalistic Writings}

Table 1 uses the Discourse Markers Model by Fraser (1999). The researcher used this in determining the DMs used by the respondents in their journalistic writings (News, Editorial, and Feature articles, respectively). 
Table 1. Discourse Markers in the Journalistic Writings of the BSED English students.

\begin{tabular}{|c|c|c|}
\hline Discourse Markers & Subclass & Sample Sentences \\
\hline Because of this & Inferential & $\begin{array}{l}\text { "In an ongoing pandemic due to CoVid-19 virus } \\
\text { disease, scientists make way for a vaccine to be } \\
\text { created as soon as possible that would prevent the } \\
\text { virus caused much more tremendous effect to people. } \\
\text { Because of this, two big companies such as Pfizer- } \\
\text { BioNtech and Moderna lead their ways to introduce } \\
\text { the vaccine of about effectiveness of } 95 \% \text { (Pfizer- } \\
\text { BiNtech) and } 94 \% \text { (Moderna)." } \\
\text { "Because of this, there are two versions of Tour A } \\
\text { available, one that goes to the Big Lagoon and } \\
\text { another which goes to the Small Lagoon." }\end{array}$ \\
\hline Additionally & Elaborative & $\begin{array}{l}\text { "Additionally, Moderna, on the other hand, } \\
\text { performed a segment where they made trials of study } \\
\text { which includes healthy adults aging 18-55 that were } \\
\text { able to be tests of the vaccine. }\end{array}$ \\
\hline
\end{tabular}

On the other hand
Contrastive

"Additionally, Moderna, on the other hand, performed a segment where they made trials of study which includes healthy adults aging 18-55 that were able to be tests of the vaccine."

"On the other hand, the Moderna vaccine was $94 \%$ effective at preventing laboratory-confirmed COVID 19 illness in people who had evidence of being previously infected based on the evidence from a clinical trial."

"However, due to novelty of the disease and the vaccine itself, a few remain skeptical about the latter safety and efficiency."

"Filipinos with law status, mostly those in cities live with constant hunger pangs barely able to afford to eat three times a day, and some children go to school without breakfast. However, President Rodrigo Duterte aims to reduce the rate of poverty to $14 \%$ by 2022.

Table 2 (continued).

Thus

Inferential
"Expected that as the clouds appear like a sea, it can only be found at the mountain. Thus, to get there, you can bring your autos or, more conveniently, your motorcycles."

"Thus, the point of healthy people getting the vaccine is so they don't spread the virus and fewer chances to 
die from COVID."

"Thus, DENR initiate a program to rehabilitate Manila Bay that makes it controversial."

Firstly/First Temporal
"Firstly, based on the evidence from clinical trials, the Pfizer-BioNtech vaccine was 95\% effective.”

"Here are five ways program to combat Poverty in the Philippines. First is greater access to education."

Hence Inferential
"Hence, the FDA reviewers said that the two-disc vaccine 'was highly effective' in preventing symptomatic.”

Table 3 (continued).

Moreover

Therefore
Elaborative "Moreover, one encouraging finding with these two
vaccines was that it appeared possible a single dose
which was effective in preventing COVID 19."

"Moreover, we must pay tribute by at least letting them know that we value their efforts through staying at home."

"Moreover, Manila Bay is known as one of the most polluted bodies of water in the world."

"Pfizer Biotech and Madonna are two licensed vaccines currently available, both in the form of the known mRNA vaccine Messenger RNA. Therefore, their structure is almost the same, and the mechanism mode is also very similar."

"Therefore, the charge will be 'dismissed for lack of probable cause' as said."

"Therefore, Manila Bay Clean Up Program has been initiated by DENR."

Table 4 (continued).

Meanwhile
Elaborative
"Meanwhile, 11 men namely: John Pascual dela Cerna III, Romel Galido, John Paul Halili, Gregorio Angelo de Guzman, Jezreel Rapinan, Alain D. Chen, Mark Anthony Rosales, Reymar Englis, Louie Delima. Jaymr Cunanan, and Eduard Pangilinan." 

at the party for welcoming New Year, January 1, 2021, when Christine was found her friends motionless as well as breathless on a tub."

"Furthermore, they call it 'Battle for Manila Bay,' and it is not a battle."

"Furthermore, they put sacrifices such as spending time beyond regular hours for emergency tasks."

"Furthermore, the government has implemented various programs and reforms to reduce poverty by targeting education, healthcare, and the overall economy."

Table 5 (continued).

In conclusion

Inferential

"In conclusion, Makati prosecutors successfully cleared their charges through the approval of a resolution by Deputy City Prosecutor Henry Salazar and City Prosecutor Dindo Ventuzara."

Finally Temporal "Finally, because of the efforts and initiatives, Manila Bay became what it is now."

"Finally, they are considered heroes in disguise who remained faithful with their duties despite the risk."

\begin{tabular}{cll}
\hline Second & Temporal & $\begin{array}{l}\text { "Second, greater access to healthcare, an effort which } \\
\text { aims the healthcare system so that those who are in } \\
\text { poverty will have more access to health services." }\end{array}$ \\
\hline Third/Thirdly & Temporal & $\begin{array}{l}\text { "Thirdly, is family aid to further efforts to support } \\
\text { citizens, the government implemented the Pantawid } \\
\text { Pamilyan Pilipino Program (4Ps) since 2007." }\end{array}$ \\
\hline Fourth & Temporal & $\begin{array}{l}\text { "Fourth is an economic improvement. } \\
\text { infrastructure plan." }\end{array}$
\end{tabular}

Table 6 (continued).

Lastly Temporal
"Lastly is Build Build Build, the initial goal is to complete the project in the infrastructure plan."

Out of the 30 articles written by the respondents, there are only $17 \mathrm{DMs}$ found. These were categorized according to their subclasses, namely Elaborative, Contrastive, Inferential, and Temporal. Surjowati (2018) explained the definitions of each subclass.

Elaborative DMs are used to signal an elaboration of an idea. There were 4 elaborative DMs found in the articles, namely, additionally, moreover, and furthermore. Among them, furthermore was mostly used with 4 sentences.

Contrastive DMs areused to signal contradicting or opposing ideas from one segment to another. There were two contrastive DMs found in the articles, namely, on 
the other hand, and however. Both of of them were used twice.

Additionally, Inferential DMs are used to signify that segment 1 has a basis for segment 2 . In the articles collected, there were five inferential DMs found. These were because of this, thus, hence, therefore, and in conclusion. Among them, both thus and therefore were used thrice, respectively.

Temporal DMs are used to signal time. In the articles, there were 6 temporal DMs found. These were first/firstly, second, third/thirdly, fourth, finally, and lastly. Among them, finally was used twice in the articles.

The result shows that the most used DMs were, furthermore, and moreover, which are elaborative DMs, and thus, and therefore inferential DMs. This means that based on their writings, they mostly use DMs for elaboration and basis about something. This reflects to the idea that the respondents' orientation in using DMs in writing focuses on using them as device for elaboration and conclusion of ideas in basic writing.

This is supported by Martínez (2004), who claimed claimed in her study that these two DMs are the most frequently used in writing. Moreover, Kusumayati (2016) also concluded that students who usually use these DMs are the ones who score the best result in their writing tasks.

\subsection{Error Analysis}

Table 2 employs the Error Analysis Model by (Corder, 1981). This enabled the researcher to identify the errors committed by the respondents in the use of DMs in their journalistic writings. The errors committed were categorized according to the different classifications of errors (Al-khresheh, 2016).

Table 7. Error Analysis of DMs in the journalistic writings of the BSED English students.

\begin{tabular}{ll}
$\begin{array}{l}\text { Classification } \\
\text { Errors }\end{array}$ & of \\
\hline \multirow{2}{*}{ Omission } & $\begin{array}{l}\text { "Meanwhile, } 11 \text { men namely: J. dela Cerna, R. Galido, J.P. Halili, Greg de } \\
\text { Guzman, Jezreel Rapinan, Alain Chen, Mark Rosales, Reymar Englis, Louie } \\
\text { Delima. Jaymr Cunanan, and Eduard Pangilinan. }\end{array}$ \\
& "Filipinos with law status, mostly those in cities live with constant hunger pangs \\
& barely able to afford to eat three times a day, and some children go to school \\
Misinformation & without breakfast. However, President Rodrigo Duterte aims to reduce the rate of \\
& poverty to $14 \%$ by 2022. \\
\hline \multirow{3}{*}{ Addition } & "Additionally, Moderna, on the other hand, performed a segment where they made \\
& of the vaccine."
\end{tabular}

The data shows that the respondents commit three out of four errors. The first is omission. The sample statement has lacking details. The DM "meanwhile" became irrelevant, and the statement is not a sentence but rather a phrase. The second is misinformation. The sample statement uses the DM "however," which is contrastive. The statement should be using an inferential DM instead of "therefore" to make the statement semantically correct. The third is addition. There are two DMs used in the sample statement, "additionally" and "on the other hand." Since this excerpt does not show contradiction, the contrastive "on the other hand" should not be used. Moreover, there was no sample statement for misordering.

Therefore, this data shows that students commit mistakes using the correct or appropriate DM to be used in a sentence. There is confusion as to the functions of each DM. This result was supported by Faghih (2015), who claimed that there are individuals who have insufficient knowledge on the selection and usage of DMs in writing. Al-khazraji (2019) further exclaimed that the incorrect usage or the overuse of DMs negatively affects the transmission of message.

\subsection{Interview Results}

The questions were designed to identify the respondents' familiarity with DMs, how often they use them in their writings and what prompted them to commit errors in using DMs.

The researcher made use of an interview guide (see Appendix E) via telephone interview. This was used 
to gather the needed responses from the participants that are essential to this study.

The respondents were Lyn, Che, Ara, Mia, Mel, Jen, Jud, Mar, Ces, and Mae (pseudonyms). They were chosen due to the diversity they have, which is suitable for this study. All of them have differences in all factors that are gauged in this study.

Their responses were classified using thematic analysis. Below are the three themes: Discourse Markers as Connectors, Frequency in Using DMs in Journalism, Confusion among the DM Subclasses, and DMs as Accessories in Writing.

\subsection{Discourse Markers as Connectors}

Most respondents are familiar with DMs as "connectors" or "connecting words" for one idea to another during the phone interview. One of the respondents shared:

Ahm..kuan, familiar siya sa akua ma'am kay naagian naman gud nako siya before ma'am, even sa kanang Senior High School nako na kuan na days until college. Na learn na nako ma'am. Gamiton nako siya ma'am kaning naa koy isumpay-sumpay na word. Kitahay kanang...especially kanang mga moreover...mga ing-ana gud ma'am? Kay connectors man gud ang kanang Discourse Markers tapos mao to kung kinahanglan nako siya kanang isumpay or kanang nay mga cause and effect...mga ingon ana gud ma'am? Kay ako ra siyang ginagamit jud, especially pag necessary najud siya, sa kanang gamiton jud siya. Kay importante man gud pud na siya sa writing.

They are familiar to me because I already knew about them during Senior High School until college. Every time I have to connect words, I use them every time, especially the word "moreover" because DMs are connectors. If I need to join or show cause and effect, I use DMs, especially if essential. Because DMs are necessary for writing.

- Mia -

Furthermore, other responses were asserted:

Kuan ma'am, kanang gi introduce na siya sa basic English na gina teach sa atua sa high school, sa elementary. Kumbaga kuan ni sila...conjunction? Mga connecting words. Kanang kuan ma'am, ginagamit nako siya pagsugod sa sentence, example pud kanang pagsumpay nimo sa una nga paragraph unya second paragraph napud. Kanang mugamit kag “moreover," ana ma'am. Tapos sa tunga-tunga pud sa paragraph, mag compare and contrast. Mag gamit ka ug kanang mga DMs.

DMs are introduced in Basic English taught in high school and elementary. More likely, these are Conjunctions? Connecting words. I use them when I start a sentence, like when I click one paragraph to another paragraph. You use the word "moreover" and the likes. Also, if we also try to compare and contrast, we use DMs.

- Ces -

Familiar ma'am, kanang mga connecting words ma'am. Ginagamit namo na sa research ma'am. Ano ma'am, if imuhang sentence is about nas laing tao, so mugamit kag kanang "on the other hand" nya naa pa kay laing isumpay. Nya pag $i$ add na siya ma'am kay mugamit kag mga "moreover" mga ana ma'am.

They are familiar with connecting words. We use them in research. We also use them if your sentence is about other people. You will use "on the other hand." Then if you have something to add, you will use "moreover" and others.

Jen -

There are also responses that DMs are used for comparing as they exclaimed:

Kuan ma'am, kanang murag gigamit siya para maconnect ang sentence ma'am or kanang us ak a mag sugod, kay murag mag gamit ka ug Discourse Markers ma'am. Para sa akua ma'am kay kana bitawng mag compare ka ma'am. Example kay naa kay i-compare tapos mag gamit $k a g$ "on the other hand"...daghan man na ma'am noh? So mao na ma'am.

I think they are words that are used to connect a sentence or before you start a sentence. For me, it is used, for example, if you are comparing something. You will use "on the other hand."

- Jud -

Familiar ma'am, especially kung mag himog sentence, like that. Naagian pud nako siya sa high school ma'am. Mao ba nanag connecting words ma'am noh? Kanang sa comparing of ideas. Ana ma'am.

It is familiar, especially in making a sentence. It is used as connecting words and comparing oof ideas. I heard it from high school.

- Che - 
Based on their answers, most of the respondents viewed DMs as connecting words, similar to conjunctions. And the term "connectors" implies showing cause-andeffect and combining ideas from one to another. Looking back on the DMs used in their journalistic writings, the way how they used them and how they describe their understanding of DMs are contradicting. Their responses showed that even if they are using DMs in their writings, they were not aware of the purpose of using DMs in writing, aside from the things they mentioned.

Moreover, their responses also reflected the idea that they were exposed to a different term for DM during high school, which is "connectors," or associating them with conjunctions. Their orientation with these words or phrases' functions in writing are to connect or link one idea to another, show cause-and-effect, and show contrasting ideas.

Shardama and Yakubu (2014) asserted that DMs are words commonly referred to as linking words/phrases and sentence connectors. They bind together a piece of writing and make them stick together. A sentence will not be logically constructed without sufficient DMs. Moreover, sentences will not be connected. In the same breath, Barnabas and Adamu (2012) suggested that the skillful use of DMs often implies a higher level of fluency of understanding and producing a language.

\subsection{Frequency of Using Discourse Markers in Journalism}

This theme discusses how often do the respondents use DMs in their journalistic writings. Most of them answered that they always or most of the time use DMs in writing. One respondent expressed:

Ma'am, as often as possible, naga gamit gyud ko ug DMs if mag sulat ko. Kay para ma organize nako ug tarong akong mga ideas ma'am. Kay for example lahi na ug idea ang next paragraph, so need nako butangan ug connectors, or words na mag indicate kung nag support ba siya sa previous idea or nag contradict ma'am. Also, para makita ang flow sa akong idea ma'am.

I use them as often as possible in writing so that I can organize my ideas well. For example, the next paragraph has different idea, I need to use connectors or words to indicate if it supports the previous idea or not. Also, to clearly see the flow of my ideas.

- Mae -

Similarly, a respondent exclaimed that she always used DMs to connect one idea to another in journalism. She explained:
In journalism...kuan siya ma'am, kuan jud siya, perminte jud siya ginagamit ma'am. Kay daghan man gud kag i-connect kanang especially kanang mga stories, pareha anang stories sa kanang news, kay kailangan man nimo siya i-connect kay daghan mag kanang interview, kailangan man jud nimo siya gamitan ana ma'am. So perminte nako siya ginagamit.

It is always used in journalism because there are many ideas that you need to connect, especially in writing news stories and interviews.

- Mia -

Furthermore, while all of them answered with almost the same idea, two respondents elaborated their opinions. They both responded how they view the importance of DMs in writing with the following declarations:

Para sa akua ma'am, katong wala pako kabalo nan aa diay mga DMs ma'am, dili nako siya ginagamit tungod lge kay wala ko kabalo kung unsa siya ka importante. Pero katong nakabalo nako ma'am, kailangan gyud diay siya gamiton permi ma'am. Na appreciate nako siya and na aware nako nga mao diay na sila ang mga ginatawag na DMs ma'am. Pag magsulat ko ma'am, na realize nako nga dapat gyud diay gamitan siya para dili gani mag putol-putol ang idea ma'am? Kanang inig basa nimo ba kay dili ka mawala nga ay lahi na diay ni ug idea diri na part. Ana ma'am.

For me, I do not use DMs because I do not know what they are. But now that I am aware, I realized how important they are. I became knowledgeable, and I appreciated DMs in writing. If I write something, I should use DMs so that the connection of ideas will be obvious. It will also help the readers understand the change of ideas

\section{- $\quad$ Mel -}

Para sa ako ma'am kay perminte gyud siya magamit ma'am. Kadaghan jud siya magamit. Kuntahay naa kay mga daghang panghitabo na makuan, mag gamit jud ka ana ma'am kay mao man nay gamiton para ma connect ang mga panghitabo ma'am.

For me, DMs are always essential to use. They are used to connect and show sequences of events. 
Based on their responses, DMs should always be used in writing. These help them connect their ideas and show transitions of topics.

One of the characteristics of DMs is connectivity. Asik (2015) claimed that DMs are used to establish a relationship between the previous utterance to the new one. This is the most common notion about the usage of DMs in writing. While DMs have many functions in writing discourse, students commonly used them as a 'glue' to link ideas. Further, they commonly use these as indicators for changing the concept in a text. Aidinlou and Shahrokhi (2012) also affirmed that DMs as the binding elements of a text creating a meaningful discourse have been viewed from different dimensions in language studies.

The data shows that even with limited knowledge of DMs, students use DMs in their journalistic writings to emphasize an idea. By using 'connecting words,' they will show further the flow of their ideas in written discourse.

\subsection{Confusion among the Discourse Markers Subclasses}

While all of them agreed to the idea that they always use DMs in writing, they also revealed that they, too, commit errors in using them and what prompted them to. Most of them said that being unconfident and unsure of what DM they should use is why they commit an error in using such.

For one respondent, she was still struggling with what exact DM should she use in conclusion as she opened:

Kuan jud, usahay jud feeling nako uncertain ko sa kong gi answer...ay gibutang. Pareha anang kuan ma'am noh, moreover, furthermore, kanang mamali ko usahay ba. Especially pud kanang conclusion na part gud ma'am? Oh, diraa o usually mamali sa kanang feeling nako murag dili man ni tama guro. depende sa kanang ano gani niya ma'am, unsa gani tawag ana uy. Kanang sa situation gani nako ma'am. Depende lang gyud sa writing na akong gamiton. Kuntahay sa kuan, ang sayon lang kanang sa cause and effect. Pero maglisod ko kana ganing sa times na...sa conclusion lang gyud akong mamali ma'am ay. Kanang malibog ko. Diraa lang gyud na part kay kanang daghan man gud kayo pud siya. Pareha anang "therefore", okay lang ban a kani akong gamiton? Or 'in conclusion'...kanang ingon ana.

Sometimes, I feel uncertain of the words I used. I usually commit error in using words like moreover, and furthermore. Especially in the conclusion part, because sometimes I feel like the words I use are inappropriate. It also depends on the kind of writing I am. The easiest for me is writing a cause-and-effect concept. But in writing the conclusion, I get confused about whether to use "therefore" or "in conclusion" since there are a lot of them.

- Mia -

Moreover, most of the respondents exclaimed that the confusion among DMs prompts them to commit an error. Since there are a lot of DMs, their confidence in using these words in writing becomes low. They are very conscious about the appropriateness of the usage as they explained:

Ma'am mamali gyud ko sa pag gamit ana ma'am ay. Malibog man gud ko sa kadaghan sa kuan ma'am...kanang mga examples bitaw niya ma'am. Usahay kay dili paka familiar gyud sa mga nagkalain-lain na DMs gyud ma'am ba. Dili ka hawd muhinumdom kung unsa ang pwede magamit para dili siya balik2x sa imong paragraph.

I usually commit errors in using DMs in writing. I am confused as to what particular DM I should use because there are a lot of them. I am not good at memorizing to avoid the redundancy of DMs.

- Ces -

Kanang makuan nako na lahi man diay siguro ang kuan uy, gamiton. Kuan ma'am, kaning sa akong huna-huna na dili man siguro ni mao ang dapat na kuan...or dili pwede gamiton. Maka isip ko nga mali diay siguro ni.

I am conscious as to what DM I should use. Sometimes I can say that this DM is inappropriate or this should not be the one to use. This makes me uncertain.

- $\quad$ Mel -

For me ma'am, yes ma'am. Kay there are a lot of examples of such discourse markers ma'am and I think na as a student, I aslo commit errors and I cannot determine what really is the appropriate DM to be used ma'am. Kuan man gud ma'am, tungod sa kadaghan ug examples ma'am na halos pare-parehas lang gani ug meaning ma'am? Malibog ka unsa gyud na word ang tama para mu connect ana na sentence ma'am.

Yes ma'am. Because there are a lot of DMs, and as a student, I still commit errors. I cannot 
determine what is the appropriate DM to be used. Because there a lot of them, some may have almost the same meaning. This makes me confused if the word that is used is correct for a particular sentence.

- Ara -

Kuan, sometimes I'm not really sure if kung kana ba siya na DM ma'am kay kanang correct ay kuan ba siya ani ma'am, kani na flow. Kay daghan man gud siyag pwede magamit ma'am. Dapat kato gyud appropriate sa journalistic writings dapat kato gyud gamiton kay usahay mamalig gamit sa kadaghan pud. Nya usahay ma tempt mag gamit ug mga words para dli mag balik2x unya mali na diay to semantically.

Sometimes, I'm unsure if this DM is appropriate because it has many functions in a sentence. It should be the most appropriate one to be used in journalistic writing. Another thing is that sometimes, we are tempted to use other synonymous words just to avoid redundancy, without thinking if it is semantically correct or not.

- $\quad$ Che -

Meanwhile, other respondents expressed that DMs should be discussed more in class. This will help them become more aware of when and how to use these words as they said:

Ma'am, malibog gyud ko sa tinuod lang. Bisan pag naka agi nami ani sa high school noh, pero kulang pagyud. Karon gud nga naga ask ka sa akua ma'am, sige kog huna-huna nga dili gyud diay enough ang akong natun-an. Kumbaga, natapsingan rani ma'am sa una. Unya...kuan, ma'am pwede mu suggest? Hehe! Kanang ma'am basin pwede unta ma discuss ni further na topic sa amuang major ma'am, especially nga daghan mig writings puhon. Like sa Campus Journ nato ma'am oh. Sige mig sulat pero kanang wala kaayo mi pake ana ma'am ba. Unya gamit diay man kaayo namo ni. Ulaw kaayo ma'am sige mi kamali unya English majors mi. Hahaha!

I still get confused with this topic even though we already discussed this in high school. Now that you are asking me about DMs, I became so conscious about how much I do not know about them at present. It's like we just randomly touched this topic without digging its core. May I suggest? *laughs* Maybe this topic may be discussed further in our significant courses, especially since we have many writings to do in the future. Like in Campus Journ, we always write articles, but we don't care about using DMs, while these are supposed to be very useful. It's a pity that we do not know much about DMs though we majored in English. *laughs*

- Ces -

In the statements mentioned above, it is evident that they lack basic knowledge of DMs. Even though most of them use DMs in writing, there is still confusion about the appropriateness of usage. Moreover, it was depicted that they also get confused about which DMs they should use since many of them.

In this manner, when one fails to use DMs properly or appropriately in writing, there will also be a failure in conveying the text's message. Hence, the coherence and cohesion in the pragmatic and semantic levels will also be affected. Since DMs in writing are essential to technical writing, misused DMs will most likely result in incoherence. Thus, their basic writing skills will be affected as a whole.

These factors prompted the respondents to commit errors in using DMs in their journalistic writings. As a result, it will affect the message of the text itself. It may lead to a misunderstanding of the meaning of the text. The mistake of the use of DMs disturbs the writing styles of the students directly. Therefore, these markers facilitate understanding of the written text (Al-khazraji, 2019).

\subsection{Discourse Markers as Accessories in Writing}

While most of the responses coming from the participants discuss their confusion with the different types or subclasses of DMs, there is one response that tells more about how DMs function in his writing as he confessed:

Ma'am, kanang bisan naga gamit ko ani sa pagsulat ma'am noh kay feeling nako mali akong pagka gamit. Murag pampanindot ra siya ma'am ba. Murag para hawd kaayo musulat tan-awon pero diay to, mali. Maong mamali kog kuan ma'am...gamit ana kay gamit rako dretso bisag unsa kutob sa mahinumduman pero di ko sure kung mao ba gyud dapat. Siguro tungod kay kulang akong prior knowledge ani ma'am ba. Unta ma discuss ni sa among klase sunod ma'am noh para mu hawd gyud mi ma'am kay feeling nako basic ni nga dapat namo mahibal-an pero wala diay mi kabalo ma'am.

Even if I use DMs in writing, I still feel that I fail to use them correctly. They are just like decorations to make my writings appealing, but they do not make sense in reality. I commit 
mistakes because I use DMs for as long as I can remember, without thinking of their appropriateness. Maybe because I lack enough prior knowledge about them, I hope this topic will be discussed further in our class because I believe this is one of the basics, but still, we fail to understand them.

- $\quad$ Mar -

Aside from the fact that there were confusions among the various types of DMs, another idea came, which is problematic. Mar only used DMs to do his writings somewhat appealing to the readers when in fact, they would not. The misuse of DMs or even other cohesive in basic writing does not make an article or a written output appealing or fancy. This will only lead to misunderstanding of the message to be conveyed by the writer to the reader. Same with speaking, a writer must also consider the target audience or the readers of their output.

In this sense, in writing, on the other hand, it is reasonable to presume that the writer is the only one who interacts with the texts during the writing process. In this scenario, the author or writer may need to consider the reader's perspective. He/she may need to play both the writer and the reader to persuade themselves that they are the ones reading their ideas (Aijmer et al., 2011).

Moreover, DMs play an essential role in achieving socially situated language communicative objectives in written and spoken discourse and include several different parts of coherence and structure (Wang \& Guo, 2014). However, despite extensive research on the functions and uses of DMs, one aspect has not yet been fully understood, namely, the factors that motivate the combination and the order of individual DMs in their sequences involving two or more adjacent elements like, but anyway, well I think or no well but actually, a phenomenon known as clustering (Heine, Kuteva and Kaltebock, 2014).

\section{CONCLUSION}

Based on the participants' responses, it was found out that they only have limited knowledge as to what DMs are and what are their functions in writing. All of them can use DMs in their journalistic writings, but not all were competent. Moreover, the respondents' orientation with DMs was limited to using them as connecting or linking words to show ideas and show comparison and cause-andeffect relationship. They often compare DMs with conjunctions.
Additionally, they often use DMs in writing without really knowing whether they used them correctly or not. This is because they lack prior knowledge. Most students commit mistakes during high school and college because teachers used other terminologies of DMs like subordinators, conjunctions, and transitional devices.

The data also showed that DMs were used in their journalistic writings placed inappropriately in a sentence. In the error analysis, it is evident that the students are not aware of the types of DMs and their specific functions in the text. The use of DMs for them, aside from what is mentioned previously, makes their sentences appealing.

To sum it all, basic writing skills employ the procedure of a good written text and depict and value coherence and cohesion. Composing many sentences without considering the cohesive ties fails to negotiate the inter-related events intended to be decoded by the reader. Thus, the presence of the journalistic discourse markers is a necessary condition to have a smooth and enjoyable written text.

\section{SUGGESTIONS AND RECOMMENDATIONS}

The findings of this study imply that the student's writing skills may be improved by incorporating the usage of DMs. Moreover, emphasizing a thorough discussion of DMs in writing is imperative to sustain the students' knowledge.

Based on the findings, the following implications for practice are offered:

For the teachers, there should be further emphasis on discussing the use of DMs in writing for the teachers, especially its different terms, to avoid confusion among the students. For this, they are encouraged to craft strategies to help students cope with the difficulties of engaging themselves with DMs and identifying their different functions in the text. This will help the students improve their writing skills and remediating the errors they usually commit in using DMs.

This study should be their basis for reviewing the syllabus and English language teaching guide, particularly in writing for the school administration. With the protocols in the curriculum, the contents of the lessons should be thoroughly evaluated to ensure that this case will be addressed. Likewise, in Journalism, this study should be the basis of improving the quality of journalistic writings, incorporating the appropriate DMs. 


\section{REFERENCES}

[1] Aidinlou, N. A., \& Shahrokhi mehr, H. (2012). The effect of discourse markers instruction on EFL learners' writing. World Journal of Education, 2(2), 10-16.

[2] Akinyode, B. F., \& Khan, T. H. (2018). Step by step approach for qualitative data analysis. International Journal of Built Environment and Sustainability, 5(3), 163-174.

[3] Al-khazraji, A. (2019). Analysis of discourse markers in essays writing in ESL classroom. International Journal of Instruction, 12(2), 559-572.

[4] Al-khresheh, M. H. (2016). A review study of contrastive analysis theory. Journal of Advances in Humanities and Social Sciences, 2(6), 49-59.

[5] Asik, A. (2015). Discourse markers in EFL setting: Perceptions of Turkish EFL teachers. Educational Research and Reviews, 10(7), 941-950.

[6] Barnabas, L., \& Adamu, M. (2012). Discourse Markers in Nigerian Television News Broadcast. British Journal of Humanities and Social Sciences, 8(1), 44-56.

[7] Corder, S. (1967). The significance of learners' errors (Vol. 5, Issue 4).

[8] Corder, S. P. (1981). Error Analysis and Interlanguage. The Modern Language Journal, 67(1), 85.

[9] Creswell, J. W. (2007). Chapter 3: Designing a Qualitative Study. In Qualitative inquiry and research design: Choosing among five approaches.

[10] Faghih, E. (2015). English Writing Skill in Terms of Discourse Markers in INTERPOL Electronic Messages Written by Non-Native and Native Police Officers: A Comparative and Contrastive Study. 2(7), 10-23.

[11] Fraser, B. (1999). What are discourse markers? Journal of Pragmatics, 31(7), 931-952.

[12] Hamed, M. (2018). Common Linguistic Errors among Non-English Major Libyan Students Writing. Arab World English Journal, 9(3), 219-232.

[13] Holloway, I., \& Wheeler, S. (2010). Qualitative Research in Nursing and Healthcare. In John Wiley \& Sons.

[14] Javadi-Safa, A. (2018). A Brief Overview of Key Issues in Second Language Writing Teaching and Research. International Journal of Education and Literacy Studies, 6(2), 12.

[15] Kusumayati, L. D. (2016). The Use of Discourse Markers in Written Discourse by Students of English. International Journal of Humanities and Social Science, 6(3), 45-56.

[16] Sadiku, L. M. (2015). The Importance of Four Skills Reading, Speaking, Writing, Listening in a Lesson Hour. European Journal of Language and Literature, 1(1), 2931.

[17] Shardama, E., \& Yakubu, S. (2014). An analysis of discourse markers in academic report writing: pedagogical implications. European Journal of Language, Linguistics and Literature, 1(1), 15-24. 